\title{
What the students bring: Examining the attributes of commencing conservatoire students
}

\author{
Don Lebler \\ Queensland \\ Conservatorium Griffith \\ University \\ Brisbane, Queensland, \\ Australia \\ Rosie Burt-Perkins \\ Royal College of Music, \\ London, UK \\ emaild.lebler@griffith.edu.au
}

\author{
Gemma Carey \\ Queensland \\ Conservatorium Griffith \\ University \\ Brisbane, Queensland, \\ Australia
}

This article is submitted exclusively to the International Journal of Music Education and, if accepted for publication, it is agreed that it will become the copyright of the International Society for Music Education. 


\section{ABSTRACT}

As the range of experiences offered by conservatoires expands to serve an increasingly diverse student cohort, it is no longer reasonable to assume that all students will fit neatly into the traditional expectations of institutions. In the 3P model of learning, the prior learning of students is one of the Presage factors that interact with Process factors to create Products of the system; all three sets of factors should be considered when exploring a learning system.

This study explores students' preconservatoire music-learning experiences and attitudes in one bachelor of (western classical) music program in the UK and a similar program in Australia, where a popular music cohort was also studied. Results indicate that prior learning experiences and expectations differ amongst all three cohorts, raising pertinent questions about the need to reject a 'one-model-fits-all' approach to curriculum development. Working from the data, potential lessons from the popular music context are proposed for consideration in the Processes of the classical context.

Keywords: classical musicians; comparative; conservatorium; popular musicians; prior learning; student expectations 


\section{INTRODUCTION}

This study examines how musicians at two institutions have learnt music prior to commencing their studies at tertiary level, and explores the relationship between this prior experience and subsequent learning in conservatoires. The attributes of students, including their prior knowledge, abilities and approaches to learning along with institutional factors including objectives, assessment practices and teaching practices, constitute what Biggs (1999) refers to as presage, those factors in place before the learning takes place. Presage interacts with process factors, which are the ways that the learning system functions to achieve its objectives, creating products that include knowledge and skills that have been acquired, how this functions and the influence the entire system has on the learning dispositions of the students. While attention is always paid to the processes and usually to the products of a learning system, the presage factors are not so frequently considered. In particular, the pre-existing learning characteristics of students, developed by their prior learning experiences, are not always explicitly taken into account when considering the appropriateness of a learning process. Students' hopes, fears and expectations are further aspects of presage that can inform understandings of what they bring to their conservatoire studies (see Burt \& Mills, 2006a).

In classical programs, the focus and direction of at least some tertiary one-to-one performance teachers largely revolves around preparation for exams, recitals, competitions and ultimately a career in performance. To this end, students are encouraged to concentrate on their major area of study through weekly one-to-one lessons with teachers considered eminent practitioners in their field. Indeed, this study shows that students entering classical degree programs have prior learning experiences that include extensive engagement with private tuition and they expect that this should continue in their conservatoire studies. It is thought that: 
this [one-to-one] type of intense learning, based on an individualized, educationally interactive exchange between master musician and student is vital to develop the highly sophisticated blend of musical, interpretative, artistic, and highly technical skills an instrumentalist or vocalist requires to become a professional musician (Wills, 1997).

An emphasis on performance is also reflected in the curriculum design and credit point allocation in many programs where performance and practical components are awarded considerable weighting, normally in excess of 50\% of a program (Carey \& McWilliam, 2007). Most students who audition for conservatoires come from a background of one-toone learning through private lessons. Many have undertaken annual external examinations where the tools for assessment are largely designed 'to rank pupils according to what they know or can do' (Bridges, 1992, p. 51). However, are there other ways in which conservatoires can structure their programs? Can we challenge these norms to add new learning experiences for conservatoire students?

Sadler (2005) rightly asserts that learning environments should be designed so that students develop the kind of evaluative expertise that will enable them to monitor and evaluate the quality of their own work while it is in progress. The development of both the inclination and ability to self-assess is important so that students can monitor progress, identify strengths and weaknesses, recognize good work and develop professional judgment (Boud, Cohen, \& Sampson, 1999; Claxton, 1999; Hattie, 2009; Sadler, 2005). The importance of preparing graduates for a diverse portfolio career has also been addressed in recent research (for example, Burt \& Mills, 2005; Johnson \& Homan, 2003; Lebler, 2007a, 2007b, 2008). It is argued by some that conservatoires can do this by offering skills development and learning experiences that are 'musically inclusive and likely to produce multi-skilled and adaptable graduates who are self-monitoring and self- 
directing in their learning, able to function across a range of activities that can constitute portfolio career ...' (Lebler, 2007b). In other recent research, Carey (2004) suggests that while the master/apprentice based model of learning might appear familiar and attractive to many students, it could have long-term negative consequences for the student as learner, possibly restricting the development of skills which may enable students to connect with different contexts and changing cultural values (Carey, 2004; Daniel, 2005; Renshaw, 2002). Given the diverse range of skills needed to meet the many challenges of the music profession and related industries, conservatoire learning systems should ensure that students are equipped with a broad range of abilities. Even though teaching practices in conservatoires may relate well to aspects of the earlier learning experiences of students, the likely outcomes for students also need to be considered before judgments on the completeness of the process can be made.

It is timely to reconsider assumptions about what students expect from their conservatoire experience and how they have learned music previously, particularly for those institutions that have to rethink their practices because of changes demanded by external factors such as the Bologna Declaration (1999) process in Europe and the Bradley Report (2008) in Australia. This study explores processes by which we can arrive at a better understanding of what the students bring with them when they arrive at the conservatoire, in order that we might factor their existing learning attributes and expectations into our considerations of modifications to teaching practices.

\section{METHOD}

This article reports results from a pilot investigation which has drawn together researchers at an Australian Conservatorium and a Conservatoire of Music in the United Kingdom. The study developed from initial contacts between two of the researchers at an 
international conference at which they both presented findings of separate studies in their own contexts. The researchers subsequently combined the questionnaire aspects of their individual studies to conduct a pilot study designed to explore the possible effects of genre and location on student experiences and outcomes. Participants were students enrolled in programs across two institutions, with Australian cohorts drawn from a Bachelor of Popular Music (BPM) program and a Bachelor of Music (BMus) program. The BPM program employs non-conventional pedagogical approaches which largely replicate popular music learning practices outside of structured environments, while the BMus program provides 'conventional' professional training for the classical and contemporary instrumentalist, vocalist or composer. A third cohort consisting of third year BMus and postgraduate students from the UK Conservatoire, which educates undergraduate and postgraduate performers, composers and conductors predominantly in the western classical tradition, was also included. Some data collected from commencing students in this location previously has also been used.

Data were collected using two instruments, each of which is part of a larger research project. Firstly, a prior learning survey was conducted with each program. The survey was conducted at the beginning of the academic year for each cohort and was based on an instrument developed by Lebler (2007b). This survey has been conducted with all students commencing the popular music program since 2003, and it investigates the prior learning experiences of students including:

- $\quad$ what kinds of music they have studied;

- their engagement with private lessons and other ways of learning music;

- the kinds of feedback used in this learning;

- the range of music making activities with which they engaged. 
The questionnaire as presented to Australian students is included as Appendix 1. The UK version, whilst identical in other respects, sought additional information about the number of lessons. Table 1 shows the breakdown of participant numbers, the date that the questionnaire was administered and the program from which the sample was drawn. In addition to descriptive statistics, inferential statistical tests were conducted to explore differences between students studying popular music and western classical music (variable 'genre'). In order to explore differences between those studying in the UK and in Australia, further inferential statistical tests compared the UK classical students and the Australian classical students (variable 'country of study’). Given that the popular music students were only present in the Australian sample, they were excluded from this part of the analysis.

Table 1: prior learning - number of students, date and cohort

\begin{tabular}{|cccc|}
\hline & Australian popular music & Australian classical & UK classical \\
\hline Number & 33 (85\% of cohort) & 147 (90\% of cohort) & 67 (32\% of cohort) \\
\hline Date & March 2007 & March 2007 & July 2007 \\
\hline \multirow{2}{*}{ Cohort } & BPM Yr 1 2007 & BMus/BMus Studies Yr 1 & BMus, MMus, PGdip \\
& & 2007 & $\&$ one BSc ${ }^{1}$ \\
\hline
\end{tabular}

Secondly, a specially designed questionnaire (Burt \& Mills, 2006a) was conducted with the two Australian programs to identify student expectations of their undergraduate education. Data collected previously from commencing students in the UK location has been used for comparison in this aspect of the study. The questions relating to this study are included as Appendix 2. The questionnaire is drawn from the Learning to Perform: Instrumentalists and Instrumental Teachers, project, funded by the Economic and Social

\footnotetext{
${ }^{1}$ Students were asked to answer the prior learning questions retrospectively
} 
Research Council (ESRC) as part of its Teaching and Learning Research Programme. It centers on students' hopes and fears, including:

- what they look forward to musically, academically and socially;

- what they anticipate (expect) musically, academically and socially;

- $\quad$ what they are concerned about musically, academically and socially.

The questionnaire allowed students to express their hopes and fears in their own words. Responses were coded for emergent themes, and analysed descriptively. Table 2 summarizes cohort information for this stage of the research.

Table 2: hopes and fears - number of students, date, cohort

\begin{tabular}{|cccc|}
\hline & Australian popular music & Australian classical & UK classical \\
\hline number & 147 (90\% of cohort) & 33 (85\% of cohort) & 62 (85\% of cohort) \\
\hline date & March 2007 & March 2007 & July 2004 \\
\hline cohort & BMus/BMus Studies & BPM commencing 2007 & BMus commencing 2004 \\
& commencing 2007 & & \\
& & & \\
\end{tabular}

Due to the pilot nature of the work, the instruments were not always applied at the same stage of students' studies in the two institutions, and the sample sizes vary across the cohorts. While we recognize this potential weakness and new data collection is underway, this article reports on the pilot stages of the collaboration, which makes use of opportunistic sampling. The rationale behind publishing at this stage is three-fold:

- to disseminate the pilot findings, which illuminate important differences between students studying different programs and those studying in different institutions;

- to draw preliminary conclusions about the impact of this work on practice; 
- to disseminate our work to the music education community at its early stages, opening our collaboration to new international colleagues.

\section{RESULTS: prior learning experiences}

Descriptive results are presented as percentages of the participants in order to provide an illustration of prior learning experiences in each of the contexts. Results from the Australian Bachelor of Music are referred to as Australian classical results, Bachelor of Popular Music results referred to as Australian popular music results, and the results from the UK Conservatoire students are referred to as UK classical results.

\section{Demographics}

While almost three quarters of the Australian popular music cohort are male, females have a slight majority in both of the classical cohorts as shown below in Table 3. Those studying popular music are, in this sample, significantly more likely to be male than those studying classical music (Pearson's Chi-square $=9.83, \mathrm{df}=1, \mathrm{p}<0.01$ ). There are no significant differences in age according to genre, while those studying in the UK are, in this sample, likely to be older than those studying in Australia (Pearson's Chisquare=87.3, $\mathrm{df}=2, \mathrm{p}<0.001)$.

Table 3: demographic information (prior learning survey)

\begin{tabular}{|cccc|}
\hline & Australian popular music & Australian classical & UK classical \\
\hline Male & $72.7 \%$ & $44.2 \%$ & $41.8 \%$ \\
\hline Female & $27.3 \%$ & $55.8 \%$ & $58.2 \%$ \\
\hline$<20$ & $57.6 \%$ & $81 \%$ & $13.4 \%$ \\
\hline $21-25$ & $33.3 \%$ & $14.3 \%$ & $67.2 \%$ \\
\hline$>25$ & $9.1 \%$ & & $19.4 \%$ \\
\hline
\end{tabular}




\section{Learning history}

Table 4 shows that there are only marginal differences between cohorts in relation to having experienced private lessons and group tuition: there is no statistical difference here according to genre or country of study. Chi-square tests ${ }^{2}$ indicate that popular music students are more likely to have learnt from bandmates (Pearson's Chi-square=29.2, $\mathrm{df}=1$, $\mathrm{p}<0.01$ ), records (Pearson's Chi-square $=18.9, \mathrm{df}=1, \mathrm{p}<0.001$ ) or video (Pearson's Chisquare $=21.4, \mathrm{df}=1, \mathrm{p}<0.01$ ) than their classical peers, who are instead more likely to have learnt through orchestras (Pearson's Chi-square=19.4, $\mathrm{df}=1, \mathrm{p}<0.001$ ). Classical students studying in Australia are more likely to have learnt from school bands (Pearson's Chisquare=14.8, $\mathrm{df}=1, \mathrm{p}<0.001$ ) or through bandmates (Pearson's Chi-square $=11.4$, $\mathrm{df}=1$, $\mathrm{p}<0.01$ ) than those studying in the UK, who are more likely to have learnt from orchestras (Pearson’s Chi-square $=11.1, \mathrm{df}=1, \mathrm{p}<0.01$ ) or masterclasses (Pearson's Chi-square=31.0, $\mathrm{df}=1, \mathrm{p}<0.001)$.

Table 4: learning history

\begin{tabular}{|cccc|}
\hline & Australian popular music & Australian classical & UK classical \\
\hline Private lessons & $94 \%$ & $97 \%$ & $100 \%$ \\
\hline Other Bands & $79 \%$ & $65 \%$ & $34 \%$ \\
\hline Classroom & $70 \%$ & $93 \%$ & $81 \%$ \\
\hline School Bands & $67 \%$ & $78 \%$ & $45 \%$ \\
\hline Friends & $67 \%$ & $41 \%$ & $19 \%$ \\
\hline Bandmates & $67 \%$ & $33 \%$ & $7 \%$ \\
\hline From Video & $58 \%$ & $24 \%$ & $18 \%$ \\
\hline Records & $58 \%$ & $29 \%$ & $25 \%$ \\
\hline Group tuition & $39 \%$ & $32 \%$ & $36 \%$ \\
\hline Masterclasses & $18 \%$ & $40 \%$ & $79 \%$ \\
\hline Orchestras & $12 \%$ & $50 \%$ & $70 \%$ \\
\hline
\end{tabular}

\footnotetext{
${ }^{2}$ Used to reflect the nominal data (i.e. classical ‘v' non-classical against bandmates ' $v$ ’ not bandmates)
} 


\section{Engagement with private lessons}

A majority of Australian popular music students have had fewer than 50 lessons, with $20 \%$ of students reporting to have had fewer than 10, as shown in Table 5 . In stark contrast, classical music students are significantly more likely to have had over 50 lessons than popular music students (Pearson's Chi-square=29.1, $\mathrm{df}=1, \mathrm{p}<0.001$ ). There are no significant differences here between the UK and Australian classical students.

Table 5: number of lessons

\begin{tabular}{|cccc|}
\hline & Australian popular music & Australian classical & UK classical \\
\hline$<10$ & $20 \%$ & $4.8 \%$ & $1.5 \%$ \\
\hline $10-20$ & $11.4 \%$ & $2.1 \%$ & $1.5 \%$ \\
\hline $20-50$ & $22.9 \%$ & & $4.5 \%$ \\
\hline$>50$ & $45.7 \%$ & $6.2 \%$ & $92.5 \%$ \\
\hline
\end{tabular}

\section{What was learnt}

As might be expected, Table 6 shows that popular music students had far less exposure to classical music learning (Pearson's Chi-square=46.6, $\mathrm{df}=1, \mathrm{p}<0.001$ ) and substantially more exposure to popular music (Pearson's Chi-square=33.1, $\mathrm{df}=1, \mathrm{p}<0.001$ ) than their classical counterparts. There were no significant differences, according to musical genre, for jazz or music theory. Classical students studying in Australia were less likely to have previously studied classical music than those in the UK (Pearson's Chi-square $=15.1$, $\mathrm{df}=1$, $\mathrm{p}<0.001$ ), while there were no significant differences for popular music, jazz or music theory. 


\begin{tabular}{|c|c|c|c|}
\hline & Australian popular music & Australian classical & UK classical \\
\hline Popular & $64 \%$ & $18 \%$ & $15 \%$ \\
\hline Theory & $52 \%$ & $63 \%$ & $58 \%$ \\
\hline Jazz & $42 \%$ & $33 \%$ & $21 \%$ \\
\hline Classical & $30 \%$ & $80 \%$ & $99 \%$ \\
\hline Other & $24 \%$ & $12 \%$ & $15 \%$ \\
\hline
\end{tabular}

\section{Feedback}

All cohorts reported a strong reliance on their own opinions and their friends as sources of feedback: there were no statistical differences between genres (see Table 7). Popular music students are more likely to have relied on audio recording (Pearson’s Chisquare=16.8, $\mathrm{df}=4, \mathrm{p}<0.01$ ) or audience comments (Pearson's Chi-square $=11.5, \mathrm{df}=4$, $\mathrm{p}<0.05$ ) than classical students ${ }^{3}$. Classical students studying in Australia sought their friends' feedback more than those studying in the UK (Pearson's Chi-square=16.4, df=4, $\mathrm{p}<0.01)$

Table 7: sources of feedback

\begin{tabular}{|cccc|}
\hline & Australian popular music & Australian classical & UK classical \\
\hline Own Opinions & $94 \%$ & $88 \%$ & $94 \%$ \\
\hline Audience & $79 \%$ & $49 \%$ & $55 \%$ \\
\hline Bandmates & $73 \%$ & $44 \%$ & $27 \%$ \\
\hline Friends & $58 \%$ & $42 \%$ & $43 \%$ \\
\hline Audio recording & $58 \%$ & $41 \%$ & $45 \%$ \\
\hline Teachers & $58 \%$ & $91 \%$ & $46 \%$ \\
\hline Family & $45 \%$ & $44 \%$ & $4 \%$ \\
\hline Video recording & $27 \%$ & $16 \%$ & \\
\hline
\end{tabular}

\footnotetext{
${ }^{3}$ Given the small sample size, the necessary assumption for Chi-square that each cell has an expected count of more than 5 was not met for the other sources of feedback, and therefore no statistical results are presented. The cut off point is taken as $20 \%$ of the cells.
} 


\section{Types and number of activities}

Popular music students have engaged in an average of five activities (s.d.=2.0), while classical music students have engaged in an average of two (s.d.=1.3). This difference is significant at the 0.001 level $(\mathrm{t}=-8.7, \mathrm{df}=36.4)$. Table 8 shows the range of these activities, with popular music students showing a greater diversity of vocal/instrumental experience than the UK classical and Australian classical cohorts. Classical students in the UK are significantly more likely to engage in a higher number of activities (mean=2.7) than those studying in Australia who engage with a mean 1.67 activities $(t=5.9, d f=105.3, p<0.001)$ as shown in Table 9.

Table 8: musical activities

\begin{tabular}{|c|c|c|c|}
\hline & Australian popular music & Australian classical & UK classical \\
\hline Vocals & $82 \%$ & $29 \%$ & $51 \%$ \\
\hline Guitar & $79 \%$ & $13 \%$ & $7 \%$ \\
\hline Composition & $79 \%$ & $20 \%$ & $22 \%$ \\
\hline $\begin{array}{l}\text { Piano } \\
\end{array}$ & $58 \%$ & $25 \%$ & $75 \%$ \\
\hline Bass & $48 \%$ & $7 \%$ & $0 \%$ \\
\hline Computer & $48 \%$ & $8 \%$ & $9 \%$ \\
\hline Other Keys & $42 \%$ & $3 \%$ & $10 \%$ \\
\hline Drums/perc & $36 \%$ & $10 \%$ & $9 \%$ \\
\hline DJ & $12 \%$ & $3 \%$ & $0 \%$ \\
\hline Woodwind & $12 \%$ & $20 \%$ & $34 \%$ \\
\hline Strings & $9 \%$ & $18 \%$ & $33 \%$ \\
\hline Brass & $3 \%$ & $12 \%$ & $9 \%$ \\
\hline Conducting & $0 \%$ & $0 \%$ & $13 \%$ \\
\hline
\end{tabular}


Table 9: number of activities

\begin{tabular}{|cccc|}
\hline & Australian popular music & Australian classical & UK classical \\
\hline 1 & $6.06 \%$ & $70.548 \%$ & $20.896 \%$ \\
\hline 2 & $9.09 \%$ & $12.329 \%$ & $26.866 \%$ \\
\hline 3 & $18.182 \%$ & $6.849 \%$ & $25.373 \%$ \\
\hline 4 & $27.273 \%$ & $5.479 \%$ & $16.418 \%$ \\
\hline 5 & $18.182 \%$ & $2.055 \%$ & $0.955 \%$ \\
\hline 6 & $6.06 \%$ & $1.37 \%$ & $0 \%$ \\
\hline 7 & $6.06 \%$ & $0 \%$ & $1.493 \%$ \\
\hline 8 & $9.09 \%$ & $0 \%$ & $0 \%$ \\
\hline 9 & $0 \%$ & $1.37 \%$ & \\
\hline
\end{tabular}

\section{RESULTS: hopes and fears}

Students were asked a series of questions about what they looked forward to, what they anticipated and what they were most apprehensive about as they began their higher education. This aspect of the study was conducted at the start of each cohort's higher education studies. Responses were categorized and the number of students including each category of response tallied for each cohort. These results are presented as percentages of each cohort to allow comparison across cohorts.

\section{Students' hopes}

Students were asked what they most looked forward to musically, other than musically, and as a learner. Across all cohorts, students hope that their higher education will allow them to make a new group of friends. While meeting like-minded people, however, is important for the UK classical and Australian popular music cohorts, this is not the case for the Australian classical students. Table 10 shows the importance students place on 
space for improvement and development, and for the opportunities that they hope will be available to them. For UK classical students, ensemble performance is a key hope.

Table 10: students' hopes for their higher education

\begin{tabular}{|cccc|}
\hline & Australian popular music & Australian classical & UK classical \\
\hline New friends & $61 \%$ & $60 \%$ & $68 \%$ \\
\hline Improving/developing & $52 \%$ & $56 \%$ & $37 \%$ \\
\hline Opportunities & $52 \%$ & $29 \%$ & $32 \%$ \\
\hline Like-minded people & $48 \%$ & $10 \%$ & $52 \%$ \\
\hline Ensemble performances & $9 \%$ & $16 \%$ & $44 \%$ \\
\hline
\end{tabular}

\section{Students' fears}

Students were asked if they were apprehensive about aspects of the lives they were about to begin in their degree programs, academically, musically or other than musically. Regardless of cohort, financial concerns were prevalent. Similarly, students expressed concern as to the musical expectations that they will encounter, worrying that these expectations would exceed their abilities. Interestingly, Australian popular music students expressed the most fears about competition and workload, while UK classical students were more concerned about music theory ${ }^{4}$ as shown in Table 11.

Table 11: students’ concerns for their higher education

\begin{tabular}{|cccc|}
\hline & Australian popular music & Australian classical & UK classical \\
\hline Finance & $48 \%$ & $41 \%$ & $71 \%$ \\
& $15 \%$ & $27 \%$ & $29 \%$ \\
\hline Musical expectations & $21 \%$ & $13 \%$ & $16 \%$ \\
\hline Competition & & & \\
\hline
\end{tabular}

\footnotetext{
${ }^{4}$ Music theory refers predominantly to aural skills in the UK context.
} 


\begin{tabular}{|cccc|}
\hline Standard expected & $15 \%$ & $12 \%$ & $2 \%$ \\
\hline Workload & $18 \%$ & $7 \%$ & $5 \%$ \\
\hline Practice vs study & $0 \%$ & $5 \%$ & $21 \%$ \\
\hline Music Theory & $3 \%$ & $5 \%$ & $15 \%$ \\
\hline Musical acceptance & $6 \%$ & $2 \%$ & $6 \%$ \\
\hline
\end{tabular}

\section{Students' anticipations}

As shown in Table 12, students' responses to these questions indicated that all cohorts anticipate that they will achieve musical goals, while UK classical and Australian classical students also anticipate achieving academically. Australian popular music students anticipate a diverse range of resources on which to draw, reflecting the technological requirements of their course. Like Australian classical students though, they do not anticipate high quality teaching.

Table 12: students’ anticipations

\begin{tabular}{|cccc|}
\hline & Australian popular music & Australian classical & UK classical \\
\hline Achieving musical goals & $30 \%$ & $44 \%$ & $53 \%$ \\
\hline Achieving academically & $9 \%$ & $27 \%$ & $40 \%$ \\
\hline Concentrating on music & $27 \%$ & $28 \%$ & $5 \%$ \\
\hline Opportunities available & $21 \%$ & $14 \%$ & $18 \%$ \\
\hline High quality teaching & $9 \%$ & $10 \%$ & $35 \%$ \\
\hline Resources available & $42 \%$ & $5 \%$ & $2 \%$ \\
\hline New teacher & $0 \%$ & $5 \%$ & \\
\hline
\end{tabular}




\section{DISCUSSION}

We divide our discussion into three broad areas of interest that arise from these results: the demographics of the cohorts, the learning histories of the students and the activities in which students engage prior to their higher education.

\section{Demographics}

In almost all the characteristics measured in this survey, there are substantial differences between Australian popular music students and the other cohorts. The striking gender differences, with more men enrolled in the Australian popular music program and more women in the Australian classical and UK classical programs, reflects literature suggesting that men are more likely to choose instruments such as guitar and drums (O’Neill \& Boultona, 1996). That this still appears to hold true after ten years suggests

that there remains work to be done in breaking down gendered stereotypes and encouraging both boys and girls to explore music outside of the 'comfort-zones' established by long patterns of gendered choice. 


\section{Learning history}

Although almost all Australian popular music students have had some exposure to private lessons, less than half have had more than 50 lessons. The majority of students in both the UK classical and Australian classical cohorts, however, engage with the master/apprentice model of learning (Carey \& McWilliam, 2007) with these students statistically more likely to have had more than 50 private lessons. Both classical cohorts also share heavy reliance on teacher feedback. The content of these lessons reflects the obvious interests of the cohorts, with popular music students more likely to have studied popular music than the classical students. Learning music from friends, bandmates, videos and recordings has been widely reported as being characteristic of popular musicians' learning (see Green, 2001, 2006; Jaffurs, 2004; Westerlund, 2006) so it is not surprising that these types of learning are significantly more common for popular music students than for classical students. It is interesting, though, to note that a strong reliance on their own opinions is common for students in all cohorts. Learning research stresses the importance of an individual's ability to monitor progress and develop self-evaluation skills and these are characteristics of music learning that are particularly valuable (McCarthy, Ondaatje, Zakaras, \& Brooks, 2004).

While there are similarities between the two classical cohorts, there are also interesting differences. Australian classical students have substantially greater engagement in feedback from friends than do UK classical students, while engagement with masterclasses and orchestras is statistically more common among UK classical students than among their Australian counterparts. In light of these differences, the similarities between UK classical and Australian popular musicians in looking forward to meeting like-minded people are particularly worthy of comment. UK classical students, who have learnt predominantly in one-to-one lessons with little peer learning from bandmates or 
school bands, appear to seek peer interaction with others who have shared their learning experiences. Indeed, ensemble music is an important anticipated part of UK classical students' time at the conservatoire. Australian popular music students, who have learnt less through one-to-one lessons and more from peer interaction, appear to seek to broaden their learning experiences to include new musicians who challenge them in new and different ways. In fact, Australian classical students, who like the UK classical cohort learnt predominantly through one-to-one lessons, appear to seek a continuation of this learning experience in their tertiary education. In matching prior learning experiences with student expectations in this manner, we can begin to build a picture of presage factors that has the potential to inform the ways in which we respond to different cohorts of incoming students.

\section{Activities}

It is in this area that the differences between cohorts are perhaps most remarkable, with popular music students having engaged in a far larger number of musical activities than the classical students. Indeed, $82 \%$ of Australian popular music students sing, and 79\% play guitar. All Australian popular music students are songwriters - at least as contributors to collaborative compositions - as this is a requirement of the selection process for their program, and $79 \%$ of the surveyed students identify composing as an activity. These differences indicate degrees of expansive learning (Fuller \& Unwin, 2003) that may inform current research into the balance between depth and breadth in conservatoire study (Burt-Perkins \& Lebler, 2008), a factor that may well influence students' abilities to engage effectively with the dominant portfolio mode of working after graduation. The UK classical students display evidence of a more developed expansive approach than the 
Australian classical students, although both cohorts lag behind the popular music students in this regard.

Indeed, both the UK classical and Australian classical cohorts express some concern as to balancing practice with academic activities, while for Australian popular music this is not an issue. Given that Australian popular music students typically engaged in four or more musical activities prior to their conservatoire education, this is not surprising, as they will be used to juggling their time and expertise. In line with the diverse professional careers that musicians need to foster, it is interesting to note that those students who are diverse before their higher education have fewer concerns about continuing this practice during it. Indeed, while the majority of UK classical students engage in three or more activities, they remain anxious about the music theory element of their course. When considered against the number of instrumental lessons experienced, this suggests that they are entering conservatoires as confident performers but not necessarily confident musicians. However, it is the UK classical students who most anticipate achieving academically, while for the two Australian contexts having time to concentrate on music is deemed to be equally, or more, important. This is unremarkable for the Australian classical cohort, the majority of whom had focused only on one musical activity. The Australian popular music cohort, on the other hand, coming from a more diverse background, may simply look forward to being able to concentrate on honing their musical skills during their time at the conservatoire. For them, 'music' appears to be more broadly defined than for the Australian classical students, and to a lesser extent the UK classical students. Knowing that students enter conservatoires not only with a host of prior learning experiences, but also with hopes, fears and anticipations that will interact with these experiences, is a potentially important tool in planning the process and product of conservatoire programs. 


\section{Implications for Process: a way forward?}

No one-to-one instruction is included in the Australian popular music process, representing a major departure from established conservatorium teaching practices in which the teacher has a dominant role in deciding what should be learnt, how that learning should occur and how well that learning has been achieved (Lebler, 2005). Although the BPM program provides a structure that must be adhered to, much of the work is selfdirected. This relates well to the prior learning of the cohort for whom the one-to-one lesson is not central to their learning. In recognition of the self-evaluation that is normal in the practice of popular music, the program has employed both peer assessment and selfassessment in addition to assessment by staff, particularly in the major study course taken by all students in each of the six semesters of the program. However, a previous reliance on self-assessment is not exclusive to the popular music cohort; both classical cohorts also report a heavy reliance on their own opinions as a source of feedback. It is possible that greater opportunities for self-assessment to be formally recognized in classical programs might be appropriate in light of this finding.

As society becomes more complex and information-rich, people will need to constantly re-think, be adaptable, and develop new problem-solving strategies for new challenges. Therefore students need to develop keen reflective thinking capabilities so they will be able to apply new knowledge to complex situations (Koszalka, Song, \& Grabowski, 2001). Australian popular music students reflect on their learning in a journal as well as a track report that details their involvement in each of the recorded tracks they submit. The reflective journal enables students not to just list their activities, but to unpack the learning they experienced in order to increase their awareness of how they learn. 
All BPM students are involved in the assessment of their peers' recorded folios, and this activity is acknowledged through the awarding of $20 \%$ of the course mark for the quality and quantity of a student's participation in this process. Students' communication skills are enhanced by the requirement to provide of well-framed feedback to the students whose work they are assessing, and this activity also enhances students' abilities to systematically assess creative work, a skill they will also apply to their own work in the self-assessment activity and in subsequent professional practice. These skills have value for all musicians, regardless of genre.

Interdependent learning activities are in play during the preparation of the recorded folios in which students are typically involved in a number of ways with each track they submit. Of 1,616 tracks submitted over five semesters between semester two 2006 and semester 2 2008, students had a single involvement in only 2\% of submissions, and in $79 \%$ of the submitted tracks, individuals were involved in four or more ways (for example, songwriting, singing, production etc). Students frequently involve others in their creative work. Only $12 \%$ of these submissions were done without the involvement of others, and $48 \%$ the submissions involved four or more participants. The acceptance of this collaborative and multifaceted work within the program relates well to the combinations of diverse activities students report in this study.

Given all students’ desire to achieve musically and academically (i.e. beyond their specialism) and to learn alongside their peers, there is little reason why peer and selfassessment cannot be integrated into classical, as well as popular, learning contexts. Although classical students' prior learning experiences tend to revolve around instrumental lessons and orchestral playing, students seek to work with their peers, whether this be through ensemble work or through friendship groups. While not arguing that the one-to-one instrumental lesson structure should be abandoned, there is argument 
to suggest that it can be complemented by listening to students' expectations and building these into the conservatoire program.

\section{Implications for Product}

Biggs (1999) refers to products of a learning system as including the acquired knowledge and skills, how that knowledge and those skills function and the influence the entire system has on the learning dispositions of the students. It can be argued that the traditional focus on performance and composition as the products of a conservatoire education may not be sufficient to prepare graduates for professional lives that are likely to include a wide range of musical and paramusical activities. Previous studies indicate that during their initial studies at the conservatorium, many students retain high expectations of a career on the concert stage with initial expectations ranking performer or composer first (Burt \& Mills, 2006b). As students progress through their education, however, this expectation tends to broaden, with students aiming for a more diverse musical career (Burt-Perkins, 2008). Indeed, a substantial proportion of graduates will not become concert-platform soloists, and may well opt for what was initially their fallback position, teaching (Burt, Lancaster, Lebler, Carey, \& Hitchcock, 2007). Although all three programs would appear well matched to the prior learning of their respective cohorts, it could be argued in the Australian classical context that the comparatively narrow focus of the traditional learning system in conservatoires may not serve all of its graduates well. Seen in the context of a diverse Australian musical sector, a narrow focus does not demonstrably produce graduates with a range of skills and abilities that equip them well for their inevitable futures.

Reflecting the characteristics explored in this study, the Australian popular music program includes training in audio engineering and production, the theory and analysis of 
popular music, information technologies, computer music technologies and music industry studies in addition to the enhancements of musical abilities that result largely from students' access to recording infrastructure and a learning community that includes their fellow students as well as staff. The resultant enhancement of abilities prepares students for autonomous practice of popular music that will frequently involve the interdependent composition, performance, recording and dissemination of their musical outputs. In the current context, this is a common mode for popular music practice. Enhancement of students' abilities to learn, to set their own agenda and monitor their own progress are explicit goals of the process. Importantly, graduates have an impressive rate of employment in the areas for which they have been trained, that is, the autonomous practice of popular music.

In the UK context, conservatoires are also beginning to respond to the need for diverse and flexible graduates. Students are typically encouraged to engage in wideranging external engagements, varying from paid performances at London museums and art galleries to playing jazz at weddings or functions. Similarly, opportunities are available for teaching experience, educational projects and other 'professional skills' such as CV preparation or arts management. Significantly, though, these experiences are most likely to be extra-curricula. In looking outwards to teaching and learning in popular music, it is possible that conservatoires specializing in classical music can learn valuable lessons in the quest to prepare students for their life-long career in music.

\section{CONCLUSION}

If education is intended to prepare students for what awaits them, programs of study must ensure that student presage factors are taken into account and utilized where appropriate, and critically, that the learning system's processes will produce outcomes that will be 
useful in students' futures. This study has demonstrated that students' prior learning experiences have been far more inclusive than might have been expected. This is particularly so for students of classical music, who may have been assumed to have been more dependant on one-to-one teaching than these results show. The range of ways all students have learnt music before their conservatoire experiences, the diverse nature of the music they have studied, their reliance on a variety of feedback mechanisms (particularly their own opinions), and the value they place on their student colleagues are all indicators that students may be ready for more a wider range of learning experiences than are currently available. The popular music program included in this study has adopted a number of alternative pedagogical and assessment approaches that relate well to the prior learning experiences and expectations of its students. Although we do not propose that these approaches should replace existing practices in classical music learning, the popular music program has demonstrated that taking the previous learning experiences of students into account can have benefits for a learning system. Instead of relying on past practices and saying 'this is the way we have to do it' we may need to 'rethink' our habits (McWilliam, 2005). While this does not necessarily mean that the traditional curriculum in tertiary music institutions should be discarded, it does mean that we should be considering what processes are necessary to prepare students more effectively for sustainable learning outcomes that are required for a portfolio career. This cannot be achieved by the mere selection or application of one model versus another. Rather it needs to be considered in terms of the characteristics of a learning environment that provides students with a diverse range of skills which will serve them well in their likely futures: a model that provides a deepening of insight among students, exposing them to a breadth of experience appropriate to a portfolio career. To achieve this is to produce 
students who are expansive learners thinking and working beyond a narrow focus, in addition to being more likely to be prepared for careers as musicians. 


\section{REFERENCES}

Biggs, J. B. (1999). Teaching for quality learning at university: what the student does. Philadelphia; Buckingham, England: Society for Research into Higher Education; Open University Press.

Boud, D., Cohen, R., \& Sampson, J. (1999). Peer learning and assessment. Assessment and Evaluation in Higher Education, 24(4), 413-426.

Bradley, D., Noonan, P., Nugent, H., \& Scales, B. (2008). Review of Australian Higher Education. Commonwealth of Australia.

Bridges, D. (1992). Doreen Bridges: Music educator. Parkville: Australian Society for Music Education.

Burt-Perkins, R., \& Lebler, D. (2008, July 15-20). 'Music isn't one island': The balance between depth and breadth for music students in higher education. Paper presented at the 17th International Seminar of the International Society for Music Education Commission for the Education of the Professional Musician Commission, Spilamberto.

Burt-Perkins, R. (2008). Learning to Perform: enhancing understanding of musical expertise. Teaching and Learning Research Programme Research Briefing 47, London.

Burt, R., Lancaster, H., Lebler, D., Carey, G., \& Hitchcock, M. (2007, June 29-July 1). Shaping the tertiary music curriculum: what can we learn from different contexts? Paper presented at the NACTMUS Conference, Brisbane.

Burt, R. \& Mills, J. (2006a). Taking the plunge: the hopes and fears of students as they begin music college. British Journal of Music Education 23(1): 51-73

Burt, R. \& Mills, J. (2006b) Vocational learning at the Royal College of Music, CENTRELINK: the magazine of the centre for education and industry. 38, 14-15. 
Burt, R., \& Mills, J. (2005, September 14-17). Charting the musical histories of students who aspire to become professional musicians. Paper presented at the Performance Matters! International Conference, Porto.

Carey, G. (2004). New Understanding of 'Relevant' Keyboard Pedagogy in Tertiary Institutions. Unpublished Doctoral Thesis, Queensland University of Technology, Brisbane.

Carey, G. \& McWilliam, E. (2007, April 10-14). Too much performing, too little learning? Reflections on pedagogical practices within the conservatoire. Paper presented at the $5^{\text {th }}$ International Research into Music Education Conference, Exeter.

Claxton, G. (1999). Wise up: the challenge of lifelong learning. London: Bloomsbury.

Daniel, R. (2005). Challenging the Orthodoxy: an alternative strategy for the tertiary teaching of piano. James Cook University, Townsville.

Fuller, A. \& Unwin, L. (2003) Learning as apprentices in the contemporary UK workplace: creating and managing expansive and restrictive participation, Journal of Education and Work 16(4): 407-426.

Green, L. (2001). How popular musicians learn: a way ahead for music education. Burlington, VT: Ashgate.

Green, L. (2006). Popular music education in and for itself, and for 'other' music: current research in the classroom. International Journal of Music Education, 24(2), 101118.

Hattie, J. A. C. (2009). Visible Learning: A synthesis of over 800 meta-analyses relating to achievement. Abingdon: Rutledge. 
Jaffurs, S. E. (2004). The impact of informal music learning practices in the classroom, or how I learned how to teach from a garage band. International Journal of Music Education, 22(3), 189-200.

Johnson, B., \& Homan, S. (2003). Vanishing Acts: an enquiry into the state of live popular music opportunities in New South Wales. The Australia Council and the NSW Ministry for the Arts, Sydney.

Koszalka, T. A., Song, H.-D., \& Grabowski, B. L. (2001). Learners' Perceptions of Design Factors Found in Problem-Based Learning (PBL) That Supports Reflective Thinking. Retrieved 12 July 2005 from www.eric.ed.gov

Lebler, D. (2005). Learning and Assessment through Recording. In E. Mackinlay, D. Collins \& S. Owens (Eds.), Aesthetics and Experience in Music Performance. Newcastle: Cambridge Scholars Press.

Lebler, D. (2007a). Getting smarter music: a role for reflection in music learning Unpublished Thesis accessed 12 December 2008 at http://adt.caul.edu.au/ Queensland University of Technology, Brisbane.

Lebler, D. (2007b). Student-as-master? Reflections on a learning innovation in popular music pedagogy International journal of music education, 25(3), 205-221.

Lebler, D. (2008). Popular music pedagogy: peer-learning in practice Music Education Research, 10(2), 193-213.

McCarthy, K. F., Ondaatje, E. H., Zakaras, L., \& Brooks, A. (2004). Gifts of the Muse: Reframing the Debate About the Benefits of the Arts. Santa Monica, CA: RAND.

McWilliam, E. (2005). Unlearning Pedagogy. Journal of Learning Design, 1(1), 1-11.

O’Neill, S. \& Boultona, M. J (1996). Boys’ and girls’ preferences for musical instruments: a function of gender? Psychology of Music, 24(2), 171-183. 
Renshaw, P. (2002). Remaking the Conservatorium Agenda Music Forum, 8(5). Retrieved 12 December 2008 from http://www.mca.org.au/web/content/view/13/6

Sadler, D. R. (2005). Interpretations of criteria-based assessment and grading in higher education. Assessment \& Evaluation in Higher Education, 30(2), 175-194.

The Bologna Declaration (1999) [Electronic Version]. Retrieved 6 January 2009 from ec.europa.eu/education/policies/educ/bologna/bologna.pdf.

Westerlund, H. (2006). Garage rock bands: a future model for developing musical expertise? International Journal of Music Education, 24(2), 119-125.

Wills, G. (1997). Submission to the West Review of Higher Education Financing and Policy [Electronic Version]. Retrieved 12 December 2008 from http://www.dest.gov.au/archive/highered/hereview/submissions/submissions/N/nac htmus.htm 


\section{Appendix 1:}

\section{How did you learn music before coming to university?}

\section{Personal Details:}

I consent to data from this survey being used in academic publications in a manner that would not identify individual participants. $\quad$ True $\square \quad$ False $\square$

Male $\square \quad$ Female

Age Less than $20 \square$

$20-25$

More than 25

What do you do?

Tick each of the activities you are involved in.

$\begin{array}{lllll}\text { Vocals } & \square & \text { Piano } & \square & \text { Woodwind } \\ \text { Guitar } & \square & \text { Other Keyboads } & \square & \text { Brass } \\ \text { Bass } & \square & \text { Computer music } & \square & \text { Strings } \\ \text { Drums } & \square & \text { DJ } & \square & \text { Composition }\end{array}$

\section{How did you learn music?}

Tick each of the ways of learning music you have been involved in.

\begin{tabular}{|c|c|c|c|}
\hline Class room music & $\square$ & From videos/DVDs $\square$ & From masterclasses \\
\hline School bands & $\square$ & Copying records & From bandmates* \\
\hline Other bands & $\square$ & Group tuition & Private lessons \\
\hline
\end{tabular}

Other bands $\quad \square \quad$ Group tuition $\quad \square \quad$ Private lessons

Orchestras $\quad \square \quad$ From friends

If you had private lessons, how many?

Less than $10 \square \quad 10-20 \square \quad 20-50 \square \quad$ More than $50 \square$

If you had any kind of formal tuition, what kinds of music did you study?

Popular Music $\square \quad$ Classical Music $\square \quad$ Jazz $\square \quad$ Other Music $\square \quad$ Music Theory $\square$

\section{Feedback:}

How often did you use these sorts of feedback in developing your music?

\begin{tabular}{|c|c|c|c|c|c|}
\hline & Constantly & Frequently & Sometimes & Rarely & Never \\
\hline \multicolumn{6}{|l|}{ Audio recording } \\
\hline \multicolumn{6}{|l|}{ Video recording } \\
\hline \multicolumn{6}{|l|}{ Teachers' comments } \\
\hline \multicolumn{6}{|l|}{ Audience reactions } \\
\hline \multicolumn{6}{|l|}{ Family feedback } \\
\hline \multicolumn{6}{|c|}{ Bandmates' feedback* } \\
\hline \multicolumn{6}{|l|}{ Friends' feedback } \\
\hline Your own opinions & & & & & \\
\hline
\end{tabular}

How often did you have access to recording facilities including home recording?
Constantly
Weekly
Monthly
3 monthly
Occasionally $\square$
Never $\square$

*'Band' is used to refer to any musical ensemble. 


\section{Appendix 2:}

Your hopes and fears:

What do you most look forward to, musically, when you start at [your institution]?

What do you most look forward to, as a learner, when you start at [your institution]?

Is there anything about the musical life of [your institution] that makes you feel apprehensive?

Is there anything about the academic life of [your institution] that makes you feel apprehensive?

What do you most look forward to, other than musically, when you start at [your institution]?

Is there anything other than musical that makes you feel apprehensive? 